\title{
Языки Франции
}

Венсан Лорензини

DOI: 10.30547/mediaalmanah.6.2020.262269

\section{Региональные языки метрополии Франции}

- эльзасский;

- баскский;

- бретонский;

-каталанский;

- корсиканский;

- западный фламандский;

- франкский (платский диалект);

- франко-провансальский (арпитанский);

- языки ойль (бургундский, шампанский, франко-контийский, галло, лотарингское наречие, нормандский, пикардийский, пуатевинско-сентонжский, валлонский);

- окситанский или языки ок (овернский, гасконский, лангедокский, лимузенский, провансальский, виваро-альпийский);

- наречия переходной языковой зоны между языками ойль и языками ок («Полумесяц»-«Le Croissant»);

•лигурийское наречие.

\section{Региональные языки} Заморских территорий

Антильские острова

-сен-мартенский креольский язык (на лексической основе английского языка);

-гваделупский креольский язык (на лексической основе французского языка);

- мартиниканский креольский язык (на лексической основе французского языка). 


\section{Les langues de France}

Vincent Lorenzini

(C) Lorenzini Vincent

chef de la Mission Langues de France et

Outre-mer, Ministère de la Culture de France

(Paris, France)

\section{Langues de France}

-Avril 1999 : rapport du professeur Bernard Cerquiglini sur les langues de France ;

- Liste avec 75 glossonymes ;

- Liste non figée qui évoluera dans les années suivantes (noms et nombre de langues).

- Langues régionales

- Langues non territoriales

- Langue des signes française

- Rapport du professeur Bernard Cerquiglini sur les langues de France (1999) ;

- Ouvrage “Les langues de France” (2003) ;

- Fiche DGLFLF "Les langues de France, un patrimoine méconnu”.

\section{Langues régionales des Outre-Mer}

Antilles

- créole martiniquais

- créole guadeloupéen

\section{Guyane}

- créole guyanais

- créoles bushinenge (à base lexicale anglo-portugaise) : saramaca, aluku, njuka,

paramaca

- langues amérindiennes : kali'na, wayana, palikur, arawak, wayang, émerillon, hmong

La Réunion

- créole réunionnais

Mayotte

- mahorais

- malgache de Mayotte 

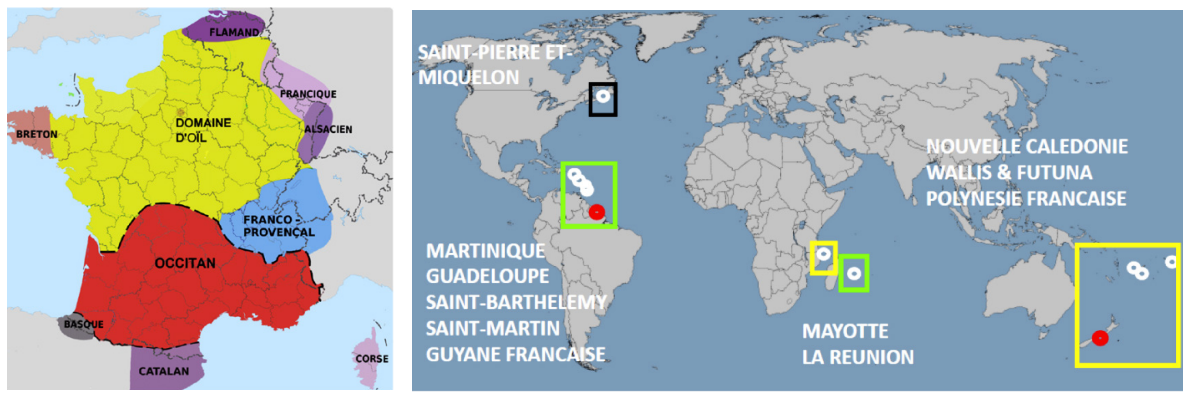

Гвиана

- апалаи (индейский язык);

- аравакский язык (локоно) (индейский язык);

-гвианский креол (на лексической основе французского языка);

-хмонг (язык, зародившийся в Лаосе);

- калина (или галиби) (язык американских индейцев);

- ненге (три языка креолов-бушиненге на английской лексической основе: алуку, нджука, парамака);

• паликур (или пахихвене) (индейский язык);

- сарамака (креольский язык на англопортугальской лексической основе);

- сранан-тонго (креольский язык на английской лексической основе);

- теко (или эмерильон) (индейский язык);

- ваямпи (индейский язык);

• ваяна (индейский язык).

Реюньон

• реюньонский креол.

Майотта

- махорэ;

• малагассийский Майотты.

\section{Французские территории на юге Тихого океана}

Новая Каледония: 29 канакских языков:

Главный остров: аджиэ, арха, архо, чаач, чемухи, диалекты вох-коне (бвато, хаэке, хавеке, хмваэке, хмвавеке, вамале, ваамванг), друбеа, фвай, хамеа-тири, яве, неку, нелемва-фвахумваак, неми, нумеэ-квеньи, ньялаю, орове, паичи, пийе, пвамеи, пвапва, сише, тайо (креольский язык на французской лексической основе), харакуу, харагуре, юанга-зуанга

Острова Луайотте: дреху, фага-увеа (полинезийский язык), иааи, ненгоне.

\section{Французская Полинезия:}

Острова Общества: таитянский Маркизские острова: маркизский Острова Туамоту: туамоту

Острова Гамбье: мангаревский

Острова Тубуаи: языки Южных островов (раивавае, риматара, рутуру, тубуаи), рапа

Уоллис и Футуна: уоллисийский, футунанский

\section{Языки Франции: определения}

Региональные языки: исторически использовались на части территории страны дольше, чем французский язык; на них говорило все население этой территории, пока французский постепенно не стал более распространен и эти языки не стали языками меньшинства. Например:
эльзасский,
баскский,
бретонский,
каталанский,
корсиканский,
креольские,
западнофламандский,
франкский,
франко-провансальский, 

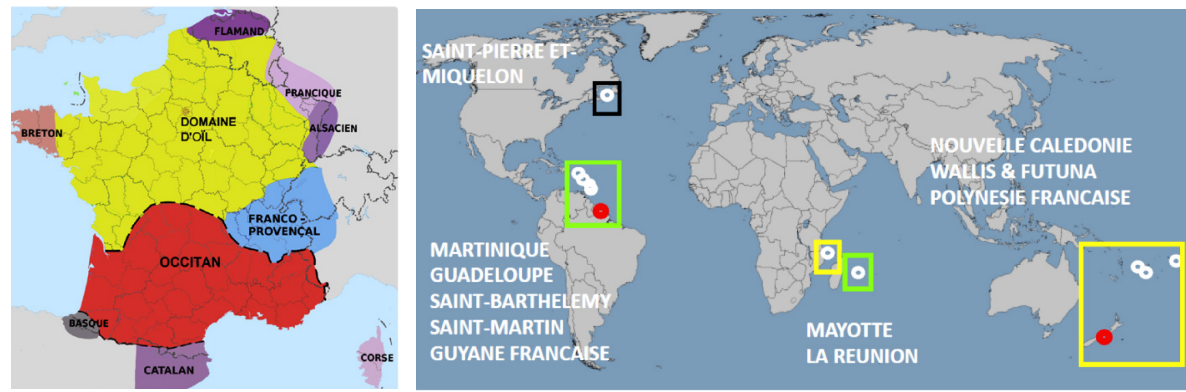

\section{Territoires français du Pacifique Sud}

Nouvelle Calédonie : 28 langues kanak

Grande Terre : nyelâyu, kumak, caac, yuaga, jawe, nemi, fwâi, pije, pwaamei, pwapwâ, langue de Voh-Koné, cèmuhî, paico, ajië, arhâ, arhö, 'ôrôê, neku, sîchë, tîrî, xârâcùù, xaragurè, drubéa, numèè

îles Loyauté : nengone, drehu, iaai, fagauvea

Polynésie française :

Archipel de la Société : tahiten

Archipel des Marquises : marquisien

Archipel des Tuamotu : langue des Tuamotu

Archipel des Gambiers : mangarévien

\section{Langues de France : définitions}

Langues régionales:

- langues historiquement parlées sur une partie du territoire national, depuis plus longtemps que le français

- langues d'usage de l'ensemble de la société de ce même territoire jusqu'à ce que le français s'impose progressivement, et qu'elles deviennent minoritaires

- langues historiquement parlées sur une partie du territoire national, depuis plus longtemps que le français

- langues d'usage de l'ensemble de la société de ce même territoire jusqu'à ce que le français s'impose progressivement, et qu'elles deviennent minoritaires

ex. : alsacien, basque, breton, catalan, corse, créoles, flamand occidental, francique, francoprovençal, langues kanak, langues d'oïl, occitan, tahitien, etc...

\section{Langues non territoriales:}

- pratiquées par de nombreux Français depuis plusieurs générations

- issues de l'immigration

- sans lien avec une aire géographique particulière de notre territoire

- sans caractère officiel dans les pays d'où elles sont originaires

ex. : arabe dialectal, arménien occidental, berbère, judéo-espagnol,romani, yiddish Archipel des Australes : langue de Ruturu, langue de Ra'ivavae, langue de Rapa, langue de Rimatara (2003), langue de Tupua'i (2003)

Wallis et Futuna : wallisien, futunien 
канакские языки,

языки ойль,

окситанский,

таитянский.

Нетерриториальные языки: используются многими французами уже несколько поколений; связаны с иммиграцией; не имеют связи с конкретной географической областью на территории Франции; не имеют официального статуса в странах происхождения. Например:

- магрибский диалект арабского;

-восточноармянский;

- берберский;

- сефардский;

-цыганский;

•идиш.

Другой нетерриториальный язык:

- Французский жестовый язык (LSF).

\section{Исторические события}

1539 г. - Ордонанс Виллер-Котре Франциска І. Французский язык используется вместо латыни в качестве официального языка права и администрации.

1794 г. - отчет аббата Грегуара о необходимости и способах уничтожить патуа и сделать всеобщим использование французского языка.

1870-1940 гг. (Третья Республика) законы Ферри (1879-1882). Бесплатное и обязательное образование для детей от 6 до 13 лет. Французский язык становится обязательным на всей территории, в том числе в колониях. Политика ассимиляции.

1951 г. - закон Дексона о преподавании местных языков и диалектов (баскский, бретонский, каталанский, окситанский). Распространение действия закона на корсиканский (1974), таитянский (1981), на четыре языка Новой Каледонии - аджиэ, дреху, ненгоне, паичи - (1992). Закон упразднили в 2000 г. и включили в Кодекс образования Франции.
1989 г. - создано Национальное управление по продвижению французского языка.

1992 г. (25 июня) - Совет Европы принял Европейскую хартию региональных языков или языков меньшинств.

1992 г. (25 июня) - Конституционный закон, согласно которому французский язык является языком Республики.

1994 г. - закон Тубона об использовании французского языка (ст. 21: Положения настоящего закона применимы наряду с законодательством и регламентными актами, касающимися региональных языков Франции, и не противоречат их использованию).

1999 г. (апрель) - Бернар Серкильини составил список языков Франции; беспрецедентное признание языкового богатства Франции.

1999 г. (7 мая) - Франция подписывает Европейскую хартию региональных языков или языков меньшинств (1992). Несмотря на то, что документ не был ратифицирован, Франция берет на себя 39 обязательств в отношении региональных языков.

2001 г. - Национальное управление по продвижению французского языка (DGLF) преобразовано в Национальное управление по продвижению французского языка и языков Франции (DGLFLF).

2003 г. - Национальное управление организует первое Национальное заседание по языкам Франции (Париж).

2005 г. - закон о равенстве прав и шансов, участии и гражданстве лиц с ограниченными возможностями (ст. 75: Французский жестовый язык признается полноценным языком).

2008 г. - поправка к Конституции от 23 июля (ст. 75.1: Региональные языки являются частью национального достояния Франции).

2011 г. - Национальное управление по продвижению французского языка и языков Франции организует в Кайенне первую Конференцию по вопросам многоязычия на Заморских территориях. 
Langues non territoriales

- arabe dialectal maghrébin

- arménien occidental

- berbère

- judéo-espagnol (2002)

- romani

• yiddish

Autre langue non territoriale

langue des signes française (LSF) (2002)

\section{Repères historiques}

1539 - Ordonnance de Villers-Cotterêts par François ler : le français remplace le latin comme langue officielle du droit et de l'administration.

1794 - Rapport de l'abbé Grégoire sur la nécessité et les moyens d'anéantir les patois et d'universaliser l'usage de la langue française.

\section{0-1940. III' République:}

Mise en place des lois Ferry (1879-1882) : enseignement gratuit et obligatoire de 6 à 13 ans. Le français est imposé sur tout le territoire, y compris dans les empires coloniaux. Politique d'assimilation.

1951 - Loi Deixonne relative à l'enseignement des langues et dialectes locaux (basque, breton, catalan, occitan). Extension de la loi au corse (1974), au tahitien (1981), à 4 langues de Nouvelle Calédonie - ajië, drehu, nengone, paicî - (1992). Loi abrogée en 2000 et intégrée au Code de l'éducation.

1989 - Création de la Délégation générale a la langue française.

25.06.1992 - Adoption par le Conseil de l'Europe de la Charte européenne des langues régionales ou minoritaires.

25.06.1992 - Loi constitutionnelle selon laquelle la langue de la République est le français.

1994 - Loi Toubon relative à l'emploi de la langue française. Art. 21 : les mesures garantissant l'emploi de la langue française s'appliquent sans préjudice de la législation et de la réglementation relatives aux langues régionales de France et ne s'opposent pas à leur usage.

Avril 1999 - Établissement de la liste des langues de France par Bernard Cerquiglini. Reconnaissance sans précédent de la richesse linguistique en France.

07.05.1999 - La France signe la Charte européenne des langues régionales ou minoritaires (1992). Malgré sa non ratification, la France prend 39 engagements en faveur des langues régionales.

2001 - La Délégation générale à la langue française (DGLF) devient la Délégation générale à la langue française et aux langues de France (DGLFLF)

2003 - La DGLFLF organise les premières Assises nationales des langues de France (Paris)

2005 - Loi pour l'égalité des droits et des chances, la participation et la citoyenneté des personnes handicapées. Art. 75 : La langue des signes française est reconnue comme une langue à part entière. 
2013 г. - отчет Консультативного комитета по продвижению региональных языков и лингвистического многообразия; определение новой государственной политики поддержки региональных языков и языкового разнообразия внутри страны.

2014 г. - издательство юридической литературы «Даллоз» (Dalloz) выпускает книгу «Языки Франции» (Les Langues de France).
2019 г. - Европейский социально-экономический комитет принял документ «Придать значимость языкам Заморских территорий для повышения уровня социальной сплоченности».

2021 г. - на о. Реюньон Национальное управление по продвижению французского языка и языков Франции планирует организовать вторую Конференцию по вопросам многоязычия на Заморских территориях. 
2008 - Révision constitutionnelle du 23 juillet. Art. 75.1 : Les langues régionales appartiennent au patrimoine de la France.

2011 - La DGLFLF organise à Cayenne les premiers États généraux du multilinguisme dans les Outre-Mer.

2013 - Rapport du comité consultatif pour la promotion des langues régionales et de la pluralité linguistique interne, Redéfinir une politique publique en faveur des langues régionales et de la pluralité linguistique interne.

2014 - Code Dalloz : Les langues de France

2019 - Adoption par le CESE de l'avis Valorisons les langues des Outre-Mer pour une meilleure cohésion sociale

2021 - La DGLFLF organisera à La Réunion la deuxième édition des États généraux du multilinguisme dans les Outre-Mer. 